\title{
Fatal infectious mononucleosis: A critical review
}

\author{
HUGH G. PENMAN \\ From the Department of Pathology, University of Otago Medical School, Dunedin, NZ
}

Infectious mononucleosis, considered here to be the same as 'glandular fever', has been regarded as a very rare cause of death. However, the number of reports said to describe fatalities from this disease has increased considerably in recent years. In 1953, Leibowitz found 38 case reports in the literature. Later, Albuquerque (1966) was able to find 50. By the end of 1969 the disease had been reported as proving fatal in at least 87 instances. In England and Wales from two to 11 deaths had been notified annually to the Registrar General (Statistical Review, 1968) during the years 1957 to 1967, and Thomsen and Vimtrup (1939) stated that they had observed even during the years 1927 to 1939 a mortality rate of about $1 \%$.

A major problem in assessing previous reports is the frequent uncertainty of the diagnosis. Many diagnoses have been based on inadequate haematological or serological data. Some have been made only after histological examination of tissues (especially spleen, liver, and lymph nodes). But although the histological changes in infectious mononucleosis may be impressive they are not specific for this disease (Carter and Penman, 1969). Because of these difficulties in interpretation, both the actual number of reported fatalities from this disease and the relative incidence of the various complications as causes of death are uncertain.

In this review, previous reports are examined critically in order to gain some idea as to how often death really has been reported in proven infectious mononucleosis, and to decide which complications may, on occasion, be fatal. The reported causes of death may be grouped thus: (1) splenic rupture; (2) neurological complications (excluding cerebral haemorrhage); (3) respiratory obstruction; (4) secondary infection; (5) liver failure; (6) miscellaneous. Each group will be

Received for publication 30 April 1970. considered in turn, the cases accepted as proven mononucleosis being clearly distinguished from those in which the diagnosis appears less certain.

To be accepted as proven infectious mononucleosis a case must have been investigated haematologically and serologically. As authors report their results in different ways the formulation of simple criteria for acceptance of cases is difficult. The haematological and serological criteria adopted in the present review are shown in Tables I and II: a case is regarded as one of proven infectious mononucleosis if at least one criterion from each group is satisfied.

The use of such strict criteria will clearly result in the exclusion of some genuine examples of infectious mononucleosis, either because tests that would have been diagnostic were not done or not repeated, or because some of the recorded cases were of the persistently seronegative type. It is impossible, however, to distinguish with certainty amongst the heterogeneous unproven cases any of genuine infectious mononucleosis, and thus the complications described in this group cannot definitely be regarded as complications of infectious mononucleosis. Nevertheless these cases will also be reviewed, and an attempt made, in the light of the clinical and laboratory data available, to distinguish those in which the diagnosis appears probable or possible from those in which it appears unlikely or frankly untenable.

The paper by Lukes and Cox (1958) must be mentioned at this point. These authors reviewed material from 30 fatal cases, supposedly of infectious mononucleosis, collected by the Armed Forces Institute of Pathology, Washington, D.C. Spontaneous rupture of the spleen was said to have been fatal in 13 of these cases, the LandryGuillain-Barré syndrome in six, and haemorrhage from the nasopharynx or gastrointestinal tract in four. The remaining seven deaths resulted from various causes; the commonest of these causes 


\begin{tabular}{llll}
\hline & Total WBC & Total Lymphocytes & Atypical Lymphocytes $^{1}$ \\
\hline $\begin{array}{l}\text { or } \\
2\end{array}$ & $5,100 / \mathrm{c} \mathrm{mm}$ or more & - & $1,400 / \mathrm{c}$ mm or more \\
or & - & $\begin{array}{l}4,500 / \mathrm{cmm} \text { or more, and at } \\
\text { least } 51 \% \text { of the total WBC }\end{array}$ & A 'significant number' \\
3 & $10,000 / \mathrm{c} \mathrm{mm}$ or more & $\begin{array}{l}\text { Description of blood film emphasizes sufficiently the } \\
\text { preponderance of mononuclear cells and the presence of } \\
\text { abnormal forms. }\end{array}$
\end{tabular}

Table I Haematological criteria for diagnosis of infectious mononucleosis

' Taken to include the 'atypical mononuclears' or similarly described cells of some authors.

\begin{tabular}{llll}
\hline & $\begin{array}{l}\text { Unabsorbed Sheep } \\
\text { Cell Agglutinins }\end{array}$ & $\begin{array}{l}\text { After Guinea-pig } \\
\text { Kidney Absorption }\end{array}$ & After Ox Cell Absorption \\
\hline 1 & Titre of 112 or more & Not reported & Not reported \\
or & Any titre & $\begin{array}{l}\text { Not less than } 12.5 \% \\
\text { of unabsorbed titre }\end{array}$ & $\begin{array}{l}\text { Zero titre, or less than } \\
12 \cdot 5 \% \text { of unabsorbed titre }\end{array}$ \\
or & Any titre & $\begin{array}{l}\text { Absorption pattern summarized as being typical of } \\
\text { infectious mononucleosis }\end{array}$ & $\begin{array}{l}\text { See } \\
\text { and }\end{array}$ \\
\hline
\end{tabular}

Table II Serological criteria for diagnosis of infectious mononucleosis ${ }^{1}$

'Data relating to other types of test, eg, those based on the use of ox cells, horse cells or papainized sheep cells, were not encountered in this review.

was secondary infection but no further details were given. Unfortunately, diagnostic data are not given in this paper, and an unknown number of the cases have presumably been reported elsewhere (eg, several A.F.I.P. cases described by Smith and Custer, 1946-see later) and are therefore likely to be included in the present review. As will be noted later, the diagnosis of infectious mononucleosis in some of Smith and Custer's cases (1946) seems very uncertain. For all these reasons the report by Lukes and Cox (1958) will not be considered further in the individual sections of the present review.

\section{Rupture of the Spleen}

Fatal splenic rupture appears to have been reported in only three cases in which the diagnosis of infectious mononucleosis can be regarded as proved. In the first case of Andersen (1939) there was a total leucocyte count of $19,200 / \mathrm{c} \mathrm{mm}$ with $66 \%$ mononuclear cells, including a considerable number of atypical forms; the sheep cell agglutinin titre was 256 with a typical infectious mononucleosis absorption pattern. In Ziegler's (1944) case, the leucocyte count was $19,000 / \mathrm{cmm}$, with $43 \%$ lymphocytes and $48 \%$ abnormal lymphocytes; the sheep cell agglutinin titre was 640. Swedberg's (1959) first case showed a leucocyte count rising to $26,900 / \mathrm{c} \mathrm{mm}$. There was an increasingly pronounced lymphocytosis, with abnormal forms, and the sheep cell agglutinin titre was 128 .

Stobbe's (1952) patient probably had infectious mononucleosis, but the unabsorbed heterophile titre, tested early in the illness, was only 32.
The two cases of Brien ${ }^{1}$ (1947) and those of Kass and Robbins (1950) and Springate and Adelsone (1966) could well have been of infectious monoo nucleosis, but in none of these instances were antemortem haematological or serological results? recorded. Likewise the case of Ramirez, Denser and Meservey (1967) appears to have been diag nosed without antemortem tests; material fromo this patient was demonstrated at the Internationa? Academy of Pathology's 1967 annual meeting at Washington, D.C., but details of the case have not yet been published in a journal. Smith and Custer's (1946) third fatal case may have been one of infectious mononucleosis. There was की marked absolute lymphocytosis with 'somet abnormal forms, but the clinical history was no typical and a heterophile agglutination tes was not done.

The diagnosis in Smith and Custer's (1946) other three fatal cases seems unlikely, in retro $\rightarrow$ spect, to have been infectious mononucleosis을 In their first case ${ }^{2}$ the lymphocyte count was normal, and atypical forms were not mentioned. Their second fatal case was initially diagnosed as 'acute gastritis'; no antemortem tests were car ried out. In their fourth fatal case, acute leukaeg mia appears to have been a more likely diagnosi than infectious mononucleosis. The immediate cause of death in their first and third fata? cases was said to have been postsplenectomyo pulmonary thromboembolism, though Custe and Smith (1948) later ascribed the first death to a transfusion reaction. In none of these three cases was a heterophile agglutination test carriect out. The authors based their diagnoses of infectious mononucleosis mainly, and in some case

${ }^{1}$ Also reported by Fisher (1946).

${ }^{2}$ Also reported by Littlefield (1946). 
entirely, on histological findings. The errors inherent in such a policy have already been mentioned, and Custer and Smith (1948) themselves listed several conditions in which cellular infiltrations of the walls of splenic vessels may resemble the infiltrations seen in infectious mononucleosis.

The cases of Spink (1954) and of Davis and Hannah (1956) were clinically atypical, and in neither was even a lymphocytosis demonstrated; in Spink's (1954) case there was no necropsy, and Davis and Hannah (1956) described findings in the spleen which were not those of infectious mononucleosis. In the case reported by Hedrick and Lettner (1965) the total leucocyte count was $88,000 / \mathrm{c} \mathrm{mm}$, and $90 \%$ of these cells were described as being 'of the Rieder variety', usually regarded as leukaemic.

\section{Neurological Complications (Excluding Cerebral Haemorrhage)}

The diagnosis of infectious mononucleosis is satisfactorily documented in nine reports in this category: those by Thomsen and Vimtrup (1939, cases 1 and 3); Ricker, Blumberg, Peters, and Widerman (19471', case 1); Dolgopol and Husson (1949); Reske-Nielsen and Mogensen (1955); Erwin, Weber, and Manning (1959); Bergin (1960); Murray (1960); and Davie, Ceballos, and Little (1963). In each of these nine cases the total leucocyte count was at least $5,100 / \mathrm{c} \mathrm{mm}$ and at least $1,400 / \mathrm{c} \mathrm{mm}$ abnormal forms were present. The sheep cell agglutinin titres were all over 112, and in several cases typical infectious mononucleosis absorption patterns were also recorded. In four of the nine cases, death resulted from respiratory weakness secondary to peripheral neuropathy of the Landry-GuillainBarré type, though Erwin et al (1959) found also severe degenerative changes in the brain at necropsy. In the other five cases the fatal respiratory difficulties appeared to be of central origin and secondary to encephalopathy. Some patients in each group developed terminal hyperpyrexia.

The diagnosis of infectious mononucleosis seems probable, or at least possible, in eight further cases of fatal neurological complication, although the available diagnostic data are often very scanty. Two cases are acceptable haematologically on the basis of either the first or the second criterion adopted in this review (Thomsen and Vimtrup, 1939, case 4, central respiratory paralysis; Klein, 1954, Landry-Guillain-Barré syndrome), but the heterophile test was not performed in the first and was negative in the

${ }^{1}$ The two cases of Ricker et al (1947) were also reported by
Peters, Widerman, Blumberg. and Ricker (1947), Custer and
Smith (1948), and by Haymaker and Kernohan (1948 and 1949). szcond. Pew's (1957) patient with a fatal Landry- $\frac{\rho}{\bar{\Xi}}$ Guillain-Barré syndrome may well have had infectious mononucleosis though the data again $\vec{\sigma}$ are insufficient for the case to be regarded as proven; the unabsorbed heterophile titre was $\overrightarrow{\vec{\rho}}$ 5,120 , but there was a polymorphonuclear leucocytosis and the lymphocytes were merely $\frac{C}{0}$ described as being 'consistent with the diagnosis' $\frac{\bar{\sigma}}{\overline{2}}$ of infectious mononucleosis. Verliac, Lamelin, $\overparen{\Phi}$ and Magloire (1963) described a patient who died $\varrho$ from encephalitis and might have had infectious $\omega$ mononucleosis. The Paul Bunnell reaction was $\vec{O}$ described as 'strongly positive', but the titre was $\overrightarrow{\vec{H}}$ not given; the leucocyte count (at an unspecified ${ }_{\sigma}$ time during the first five days of illness) was $\widehat{ }$ $15,000 / \mathrm{c} \mathrm{mm}$, with $80 \%$ polymorphs, and 'quel-? ques rares mononucléaires très basophiles'. Ström's $\omega$ (1960) young man with fatal 'polyradiculitis' was merely mentioned in passing, no further or details being given. According to Hafström (1963), 0 single fatalities were also recorded by Thomsen (1942) and by Knick and Hoffmann (1953). $I_{\bar{\sigma}}$ have been unable to see the original descriptions, $\stackrel{\mathbb{D}}{\circ}$ but Hafström (1963) stated that Knick and $\frac{\Phi}{3}$ Hoffmann's (1953) diagnosis of infectious mono- 유 nucleosis was 'serologically verified'. The first of these deaths was said to have resulted from $\vec{\theta}$ central respiratory paralysis secondary to ence- $\sigma$ phalitis, and the second from polyneuroradiculitis. In case 5 (central respiratory paralysis) of Thomsen and Vimtrup (1939) the diagnosis of infectious mononucleosis is very difficult to assess as the patient was a 13-month-old child; the changes in lymphocyte numbers and morphology are therefore hard to interpret, and the heterophile test was not performed. The case can perhaps be regarded as possibly having been one of infectious mononucleosis.

The second case of Ricker et al (1947), the fourth (and only fatal) case of Silversides and 0 Richardson (1950), and Nixon's (1952) fatal case did not yield satisfactory evidence of infectious $\delta$ mononucleosis either haematologically or sero- $₹$ logically. Judged by the antemortem laboratory data, none of these three cases seems likely to $\supset$ have been of this disease, though in the first mentioned instance the necropsy findings were similar to those seen in infectious mononucleosis.

\section{Respiratory Obstruction}

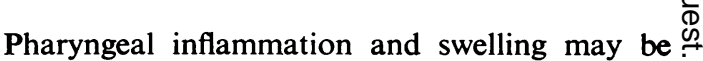
very severe in infectious mononucleosis. Reports $\square$ of death from respiratory obstruction, however, are rare indeed, and none has been found in which $\stackrel{\odot}{\odot}$ the diagnosis of infectious mononucleosis is $\stackrel{\mathbb{Q}}{\varrho}$ satisfactorily proven.

Knorre (1963) reported two fatal cases of oedema of the glottis; both cases are acceptable $\frac{\text { O }}{0}$ haematologically as infectious mononucleosis, but Paul-Bunnell tests were negative. Natvig 
(1962) described a death from pseudomembranous laryngotracheitis; in this case the serological findings were typical of infectious mononucleosis, but the haematological data are incomplete. Custer and Smith (1948) and Werner (1954) each reported a death from oedema of the glottis, but in neither paper are the results of antemortem tests given.

The case reports by Bellotti (1896, case 1 , cited by Leibowitz, 1953), Moir (1930, ruptured retropharyngeal abscess), and by Wunderlich Rupprecht, and Irmscher (1967, bronchial compression by enlarged lymph nodes) contain very meagre diagnostic data. It seems probable, on clinical grounds, that none of the three patients really had infectious mononucleosis and such haematological data as are included in the third of these papers also militate against the diagnosis.

\section{Secondary Infection}

Extreme granulocytopenia is very rarely recorded in infectious mononucleosis, and serious infection resulting from this complication is even rarer (Penman, 1968). The fatal case described by Worlledge and Dacie (1969) appears to have been almost certainly an example of this sequence of events; sheep cell agglutinins were demonstrated at a titre of 160 , with a typical infectious mononucleosis absorption pattern, but full haematological data were not given. The fatal cases of Lange (1934, case 3) and ElmenhoffNielsen (1935) may also have been instances of granulocytopenia and infection in infectious mononucleosis, but in neither was the diagnosis of infectious mononucleosis proved. No other report of alleged fatal granulocytopenia in this disease can be traced.

There are several papers which have been quoted as recording fatal secondary infection in infectious mononucleosis, with no mention of severe granulocytopenia. Amongst the cases described in these papers are three in which the diagnosis of infectious mononucleosis is satisfactorily documented: case 2 of Andersen (1939), case 2 of Thomsen and Vimtrup (1939), and case 1 of Kouba, Viklický, and Srámková (1961). In all three of these cases the leucocyte count exceeded $15,000 / \mathrm{c} \mathrm{mm}$, with a mononuclear preponderance, and at least $3,000 / \mathrm{c} \mathrm{mm}$ atypical forms. In the first two cases the sheep cell agglutinin titre was 64 , in the third it was 896; in all three the absorption pattern was of the infectious mononucleosis type.

Seven other case reports have been traced which describe fatal infections complicating what may have been infectious mononucleosis. Heilmeyer and Begemann (1951) mentioned a death from streptococcal retrotonsillar abscess. The heterophile titre was 128 , but the only haema- tological information given is that there was 'typischen Blutbild'. This case cannot therefore be accepted as proven infectious mononucleos: although the diagnosis seems very probably to have been correct. The same authors, withoūt giving diagnostic details, stated that a case of infectious mononucleosis complicated by fatad 'otitis and sepsis' was reported by Trémolière, Lereboullet, and Duret (1939). The patiegt described by Du Bois (1930) and patient 6 of Thomsen and Vimtrup (1939) both showed leucocytosis exceeding $12,000 / \mathrm{c} \mathrm{mm}$, more tha half the cells being mononuclear forms, amongst them many monocytoid large lymphocytes. 䍀 neither case, however, were heterophile teș\$s carried out; indeed both were investigated before the introduction of such tests. Gooding (19397) referred to a death from bilateral basal broncho pneumonia, and Dalrymple (1968) mentioned personal communication from M. V. McDermopt about a fatal bacterial endocarditis after a long illness with jaundice; no further details were recorded in either paper. The second case \&f Kouba et al (1961) may also have been an example of fatal secondary infection in infectio mononucleosis; death was ascribed to interstitiâl pneumonia, but again no antemortem labor tory evidence of infectious mononucleosis wæ presented.

The diagnosis of infectious mononucleosłs seems unlikely, on the evidence available, in the case described by Korsakoff (1905) and cited Leibowitz (1953); nephritis and empyema we complicated by a fatal septicaemia.

\section{Liver Failure}

Only two cases of fatal liver failure in prove् infectious mononucleosis appear to have been reported. These are the case of Allen and BaSs (1963) and the first case of Harries and Ferguson (1968). In the first there was a total leucocyle count of $11,000 / \mathrm{c} \mathrm{mm}$, with a mononuclest preponderance and 'numerous' atypical forms; the heterophile titre, after guinea-pig kidneg absorption, rose to 128 . In the second, the highest leucocyte count was $26,000 / \mathrm{c} \mathrm{mm}$, with 23,40 \% c mm 'atypical monocytes'; the heterophile titce was 112 , with a typical infectious mononucleos absorption pattern.

Ainley's (1949) patient may well have hade infectious mononucleosis, but as atypical leucocytes are not mentioned in the case report the diagnosis must be regarded as unproved. Marshal and Millingen (1952) reported a death from corn. bined renal and hepatic failure; the heterophife titre was 256 (apparently after guinea-pig kidney absorption), but the highest recorded monenuclear cell count was only $3,510 / \mathrm{c} \mathrm{mm}$ and the highest count of atypical forms only $720 / \mathrm{c} \mathrm{mm}$. Natvig (1962) referred to a thesis by Bennifere 
(1960) in which it appears that four fatalities from hepatitis are described, but the original work is not available. Finch (1969) stated that the fatal case of hepatic necrosis described by Koizumi, Kihara, and Kitamoto (1967) was not well documented, so that in this case, too, the diagnosis of infectious mononucleosis can only be regarded as possible. The same applies to the case of fatal hepatitis in a young child referred to in passing by Bolin, Chase, Alsever, and Mann (1965); 'all haematological criteria' for the diagnosis of infectious mononucleosis were said to have been met, but no details were given and heterophile tests were not mentioned.

The diagnosis of infectious mononucleosis seems unlikely in the second cases of Swedberg (1959) and of Harries and Ferguson (1968). Swedberg's patient showed a curious combination of anaemia, gastrointestinal bleeding, subcapsular hepatic necrosis, and possible haemolysis; repeated leucocyte counts failed to show lymphocytes in greater numbers than about $1,000 /$ c $\mathrm{mm}$, and the highest heterophile titre was only 32. Harries and Ferguson's (1968) patient was originally thought to have leukaemia; the authors' only reason for changing the diagnosis in retrospect appears to have been that the patient's sister later developed infectious mononucleosis. Furthermore, no evidence at all is offered to support the diagnosis of 'liver failure' and the serum bilirubin was only $0.4 \mathrm{mg} / 100 \mathrm{ml}$.

Apart from causing early fatal liver failure, infectious mononucleosis is sometimes alleged to cause more long-lasting liver damage which may ultimately prove fatal. This possibility is very difficult to refute, but so far there is no convincing evidence of its actually having occurred (see Carter and Penman, 1969).

\section{Miscellaneous}

Jersild (1942) described a death in proven infectious mononucleosis possibly resulting from myocarditis. The total leucocyte count was $29,100 / \mathrm{c} \mathrm{mm}$, with $12 \%$ lymphocytes, $6 \%$ monocytes, and $32 \%$ monocytoid cells; the heterophile titre was 256. Two deaths have been reported from causes unrelated to infectious mononucleosis. Allen and Kellner (1947) described a patient ${ }^{1}$ who had recovered clinically from proven infectious mononucleosis but who showed persistent histological abnormalities at necropsy after death in an aeroplane crash; Sharp (1950) reported a proved case of infectious mononucleosis in which death resulted from pneumothorax. In the first of these two cases, the highest total leucocyte count recorded was $11,450 / \mathrm{c} \mathrm{mm}$, with $77 \%$ lymphocytes and $9 \%$ monocytes; later, $83 \%$ atypical lymphocytes were recorded. The heterophile titre was 896 . In the

${ }^{1}$ Also included in report by Custer and Smith (1948). second case, the highest total leucocyte count $\frac{\rho}{5}$ was $26,500 / \mathrm{c} \mathrm{mm}$, including 7,155 lympho- 0 cytes and 12,455 'large lymphoid and plasma cells'. The heterophile titre was 512 .

Goldstein and Porter (1969) reported throm- $\Rightarrow$ bocytopenia and fatal cerebral haemorrhage in a $\stackrel{5}{+}$ probable case of infectious mononucleosis. The? total leucocyte count rose to $9,300 / \mathrm{c} \mathrm{mm}$ with $85 \%$ lymphocytes, 'many' of them atypical, but $\frac{\text { }}{-}$ the heterophile titre nearly three weeks after $\unrhd$ the onset of symptoms was only 14 , and detailed $\%$ results of the absorption technique were not $\vec{O}$ specified. Infectious mononucleosis may also have been the underlying cause of death in the fatal $\vec{\omega}$ case of 'toxaemia' described by Leunda, Panizza, Blanco, and Raggio (1943) and quoted by Bethell, 0 Sturgis, Mallery, and Rundles (1944) and by N Sharp (1950). The highest recorded total leuco-io cyte count in this case was $19,200 / \mathrm{c} \mathrm{mm}$, with $24 \%$ lymphocytes and $21 \%$ monocytes, but no more details about these cells are available. The $\supset$ heterophile titre was 128. Shinton and Hawkins (1956) reported a death from toxaemia, and Fish and Barton (1958) one from pulmonary embolism尺 secondary to myocarditis and intracardiac thrombosis. Although both these cases were serologically positive for infectious mononucleosis, in neither $\vec{\theta}$ were any of the present haematological criteria satisfied. The diagnosis of infectious mononucleosis can therefore only be regarded as aO possibility. The same applies to three further cases in which no antemortem diagnostic data

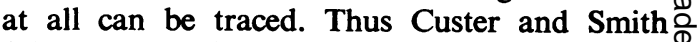

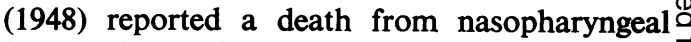
haemorrhage without providing any such infor- $\overrightarrow{\overrightarrow{0}}$ mation. Ondrŭs (1958, cited by Kouba et al, 1961) reported another fatality but the original paper is not available. Lou (1959) described briefly? the necropsy findings in an epidemic case of 'glandular fever', but gave neither details of ante-? mortem tests nor of what was considered to be the ultimate cause of death.

There seems to be little reason to suppose that the single cases of Roux and Lannois (1890), 0 Desplats (1894), and Bellotti (1896, case 2), and the three cases of Haken (1927), were really instances of infectious mononucleosis (see Sharp, 1950, and Leibowitz, 1953). Similarly, this $N$ diagnosis seems unlikely in West's (1896) fatal N case, his patient being 'a delicate child convalesc-N ing from scarlet fever'.

\section{Conclusion}

In the literature up to the end of 1969,87 reports have been found that either themselves purport $\frac{?}{\mathbb{D}}$ to describe death in infectious mononucleosis or $\varrho$ else have subsequently been alleged to do so. For reasons given earlier, the $\mathbf{3 0}$ cases mentioned $\delta$ by Lukes and Cox (1958) may not have been? included in this total. 
Of the 87 reports, 16 have been assessed only by the examination of other papers which quoted them, the originals proving unobtainable. None of these 16 cases could be regarded as being of proven infectious mononucleosis on the basis of the information obtained in this indirect fashion. Of the 71 accessible case reports, only 20 contain adequate evidence for a definite diagnosis of infectious mononucleosis. Many of the remaining 51 include some evidence in favour of this diagnosis, but it is in varying degree incomplete. The diagnosis in all cases occurring before 1932 has necessarily to be regarded as unproven, since the heterophile test was not described until that year. In about a third of the 67 cases that have had to be regarded as unproven (including those described in inaccessible original reports), the evidence available seems, in retrospect, to be against, rather than in favour of, the diagnosis of infectious mononucleosis.

Amongst the 20 proven cases of infectious mononucleosis neurological complications were fatal in nine, secondary infection and splenic rupture in three each, hepatic failure in two, and possibly myocarditis in one. In the other two cases, death resulted from causes apparently unrelated to infectious mononucleosis. Consideration of all the reports that have been traced, regardless of diagnostic criteria and including the reports not seen in the original, also indicates a preponderance of neurological deaths, followed by deaths from splenic rupture and secondary infection.

The actual proportion of clinical cases of infectious mononucleosis proving fatal from all causes is very difficult to assess. If the approximate annual incidence of the disease as seen by doctors is taken as 38 per 100,000 general population (Penman, 1966), and six as the average number of deaths annually from infectious mononucleosis in the $48,000,000$ population of England and Wales (Registrar General, 1968), then the fatality rate works out at one per 3,000 cases approximately. Most fatal cases of infectious mononucleosis in England and Wales are probably registered as such, but, as shown in this review, the diagnosis is also made in some fatal cases in which infectious mononucleosis seems really not to have occurred. Furthermore, many patients with mild attacks may not present to their doctors (Penman, 1966). Thus the real mortality rate in infectious mononucleosis is probably less than 1 per 3,C00 cases.

The scarcity of satisfactory reports of splenic rupture as a cause of death is surprising. Rupture of the spleen is widely thought to be the principal serious hazard in infectious mononucleosis. Possibly this belief has deterred those who have observed it as a cause of death from reporting their cases.

Infectious mononucleosis is at present very much in the limelight. Its possible fatal outcome may well have been overemphasized. Very few⿳亠口冋. properly documented cases of fatal infectious mononucleosis are on record, and any future $\overrightarrow{5}$ fatal cases would be worth recording, provided $\%$ that adequate diagnostic data are available and are included in the reports.

I am grateful to Professor A. Wynn Williams for encouragement, advice, and help with thes manuscript, and to Dr P. B. Jørgensen for $\vec{\circ}$ patiently helping me to translate the Scandina vian literature.

\section{References}

Ainley, N. J. (1949), A fatal case of infectious mononucleosis with extensive zonal necrosis of the liver. Ulster med. J., 18, 219-224.

Albuquerque, D. B. (1966). Spontaneous rupture of the spleen complicating infectious mononucleosis. J. Indian med Ass., 46, 562-563.

Allen, U. R., and Bass, B. H. (1963). Fatal hepatic necrosis in glandular fever. J. clin. Path., 16, 337-341.

Allen, F. H., Jr., and Kellner, A. (1947). Infectious mononucleosis An autopsy report. Amer. J. Path., 23, 463-477.

Andersen, H. C. (1939). Letalt forløbende tilfælde af mono $\overrightarrow{0}$ nucleosis infectiosa. Nord. Med., 4, 3863-3864.

Bellotti, M. (1896). Febbre glandolare. Raccogli. med., 21, 269-278:

Bender, C. E. (1958). Interpretation of hematologic and serologid findings in the diagnosis of infectious mononucleosis? Ann. intern. Med., 49, 852-865.

Bennike, T. (1960). Studier over Leveraffektionen ved Mono nucleosis infectiosa, etc. Liver Studies in Infectious Mono@ nucleosis and Some Acute Infectious Diseases with Specia Regard to the Occurrence of Chronic Sequelae. Munksgaard Copenhagen.

Bergin, J. D. (1960). Fatal encephalopathy in glandular fever J. Neurol. Neurosurg. Psychiat., 23, 69-73.

Bethell, F. H., Sturgis, C. C., Mallery, O. T., Jr., and Rundles R. W. (1944). Blood: A review of the recent literature Arch. intern. Med., 74, 131-152.

Bolin, V. S., Chase, B. S., Alsever, J. B., and Mann, F. D. (1965) Virus hepatitis test. (Abstr.) Fed. Proc., 24, 159.

Brien, F. S. (1947). Infectious mononucleosis-complications:Canad. med. Ass. J., 56, 499-502.

Carter, R. L., and Penman, H. G. (1969). Histopathology of infectious mononucleosis. In Infectious Mononucleosis尺 edited by R. L. Carter and H. G. Penman, pp. 146-16103 Blackwell, Oxford.

Custer, R. P., and Smith, E. B. (1948). The pathology of infec음 tious mononucleosis. Blood, 3, 830-857.

Dalrymple, W. (1968). Systemic effects of mononucleosis. Post grad. Med., 43, 158-161.

Davidsohn, I., and Lee, C. L. (1969). The clinical serology of infectious mononucleosis. In Infectious Mononucleosis edited by R. L. Carter and H. G. Penman, pp. 177-200. Blackwell, Oxford.

Davie, J. C., Ceballos, R., and Little, S. C. (1963). Infectioußf mononucleosis with fatal neuronitis. Arch. Neurok (Chic.), 9, 265-272.

Davis, J. M., and Hannah, L. G. (1956). Spontaneous rupture of the spleen due to infectious mononucleosis. Report of case. N.Z. med. J., 55, 491-492.

Desplats, H. (1894). Note sur un cas de fièvre ganglionnaire o@ d'adénie aigüe terminé par la mort. J. Sci. méd. Lille, 2, 73-78.

Dolgopol, V. B., and Husson, G. S. (1949). Infectious monō nucleosis with neurologic complications: Report of fatal case. Arch. intern. Med., 83, 179-196.

Du Bois, A. H. (1930). De la pathogénie de l'angine à monocytes Acta med. scand., 73, 237-259.

Elmenhoff-Nielsen, B. (1935). Ein Fall von Mononucleosi? infectiosa mit Úbergang in Agranulocytose. Acta otolaryng. (Stockh.). 22, 584-591.

Erwin, W., Weber, R. W., and Manning, R. T. (1959). Comp cations of infectious mononucleosis. Amer. J. med. Sci 호. 238, 699-712. 
Finch, S. C. (1969). Laboratory findings in infectious mononucleosis. In Infectious Mononucleosis, edited by R. L. Carter and H. G. Penman, p. 59. Blackwell, Oxford.

Fish, M., and Barton, H. R. (1958). Heart involvement in :n'ectious mononucleosis. Arch. intern. Med., 101, 636-644.

Fisher, J. H. (1946). Visceral lesions of actute infectious mononucleosis. A report of two cases with fatal spontaneous rupture of the spleen. Amer. J. Path., 22, 651-652.

Goldstein, E., and Porter, D. Y. (1969). Fatal thrombocytopenia with cerebral hemorrhage in mononucleosis. Arch. Neurol. (Chic.), 20, 533-535.

Gooding, S. E. F. (1931). On glandular fever or infective mononucleosis. Practitioner, 127, 468-483.

Hafström, T. (1963). Neurological complications of mononucleosis. Acta neurol. scand., 39, 69-81.

Haken (1927). Monozytenanginen mit letalem Ausgang. Disch. med. Wschr., 53, 565-566.

Harries, J. T., and Ferguson, A. W. (1968). Fatal infectious mononucleosis with liver failure in two sisters. Arch. Dis. Childh., 43, 480-485.

Haymaker, W., and Kernohan, J. W. (1948). The LandryGuillain-Barré syndrome. A clinicopathologic study of 50 fatal cases. Trans. Amer. neurol. Ass., 73, 17-20.

Haymaker, W., and Kernohan, J. W. (1949). The LandryGuillain-Barré syndrom:. Medicine (Baltimore), 28, 59-141.

Hedrick, K. E., and Lettner, H. T. (1965). Rupture of the spleen. Infectious mononucleosis complicated by rupture of the spleen: a report of three cases. J. Kans. med. Soc., 66, 374-377.

Heilmeyer, L., and Begemann, H. (1951). Blut und Blutkrankheiten. (Handbuch der inneren Medizin, 4th ed., edited by G. v. Bergmann, W. Frey, and H. Schwiegk, vol. 2.) p. 568. Springer Berlin.

Jersild, T. (1942). Mononucleosis infectiosa med letalt forløb. Nord. Med., 14, 1705-1706.

Kass, E. H., and Robbins, S. L. (1950). Severe hepatitis in infectious mononucleosis. Report of a case with minimal clinical manifestations, and death due to rupture of the spleen. Arch. Path., 50, 644-653.

Klein, M. (1954). The Guillain-Barré syndrome in infectious mononucleosis. Confin. neurol. (Basel), 14, 232-253.

Knick, B., and Hoffmann, K. (1953). Das Landry-GuillainBarré-Syndrom als neurotrope Manifestation der infektiösen Mononucleose. Z. klin. Med., 151, 143-152.

Knorre, D. (1963). Zur pathologischen Anatomie der Mononucleosis infectiosa. Zbl. allg. Path. path. Anat., 104, 273-277.

Koizumi, F., Kihara, I., and Kitamoto, S. (1967). An autopsy case of infectious mononucleosis terminating an acute clinical course. (Japanese.) Acta haemat. jap., 30, 286-295.

Korsakoff, N. S. (1905). Beiträge zur Lehre des Drüsenfiebers. Arch. Kinderheilk., 41, 321-357 and 42, 193-247.

Kouba, K., Viklický, J., and Srámková, L. (1961). Letale Fälle von infektiöser Mononukleose. Virchows Arch. path. Anat., 334, 173-180.

Lange, J. (1934). Febris glandularis lymfaemoides. Norsk. Mag. Lagevidensk., 95, 32-50.

Leibowitz, S. (1953). Infectious Mononucleosis. Grune and Stratton, New York.

Leunda, J. J., Panizza Blanco, and Raggio, O. V. (1943). Angina gangrenosa monocitica mortal. Arch. argent. Pediat., $19,461-462$

Littlefield, J. B., Snr. (1946). Spontaneous rupture of the spleen. Surg. Gynec. Obstet., 82, 207-211.

Lou, F. T. (1959). Infectious mononucleosis: A review of 572 cases. China med. J., 79, 175-177.

Lukes, R. J., and Cox, F. H. (1958). Clinical and morphologic findings in 30 fatal cases of infectious mononucleosis. (Abstr.) Amer. J. Path., 34, 586.

Marshall, S., and Millingen, K. S. (1952). Unusual features in a fatal case of infectious mononucleosis. Brit. med. J., 1, 1325-1327.

Moir, J. I. (1930). Glandular fever in the Falkland Islands. Brit. med. J., 2, 822-823.

Murray, U. (1960). Mononucleosis infectiosa med neurologiska komplikationer. Svenska Läk.-Tidn., 57, 1425-1428.

Natvig, J. B. (1962). Infectious mononucleosis with multiple organ involvement complicated by pseudomembranous laryngotracheitis. An autopsy report. Acta path. microbiol. scand., 56, 353-361.

Nixon, R. K., Jr. (1952). Infectious mononucleosis and the Guil-0 lain Barré syndrome; a review of the literature and the report of two cases. Illinois med. J., 102, 316-320.

Ondrus, B. (1958). Letálný príipad inf. mononukleózy. Bratisl." lék. Listy, 38, 484.

Penman, H. G. (1966). The incidence of glandular fever. J. Hyg. (Lond.), 64, 457-464.

Penman, H. G. (1968). Extreme neutropenia in glandular fever. J. clin. Path., 21, 48-49.

Peters, C. H., Widerman, A., Blumberg, A., and Ricker, W. A., Jr. (1947). Neurologic manifestations of infectious mono- $\mathbb{D}$ nucleosis, with special reference to the Guillain-Barré syndrome. Arch. intern. Med., 80, 366-373.

Pew, W. L. (1957). Neurologic manifestations of infectious mononucleosis. Northw. Med. (Seattle), 56, 695-698.

Ramirez, R. M., Denser, C. H., and Meservey, M. D. (1967). Synopsis of demonstrations at the annual meeting of the $\vec{\omega}$ International Academy of Pathology, Washington, D.C.W

Registrar General (1968). Statistical Review of England and Wales for 1967. Part I, Tables, Medical, p. 15. HMSO, London?응

Reske-Nielsen, E., and Mogensen, E. F. (1955). Mononucleosis associated with Landry-Guillain-Barre's syndrome. Report $\omega$ of a fatal case. Acta haemat. (Basel), 13, 387-392.

Ricker, W., Blumberg, A., Peters, C. H., and Widerman, A. (1947). The association of the Guillain-Barre syndrome with infectious mononucleosis, with a report of two fatal cases. Blood, 2, 217-226.

Roux, G., and Lannois, M. (1890). Sur un cas d'adénie infectieuse due au staphylococcus pyogenes aureus. Rev. med., 10, 1011-1034.

Sharp, M. E. (1950). Infectious mononucleosis: report of a case with autopsy. J. Path. Bact., 62, 175-187.

Shinton, N. K., and Hawkins, C. F. (1956). A fatal case of glandular fever. Lancet, 2, 708-709.

Silversides, J. L., and Richardson, J. C. (1950). Neurological complications of infectious mononucleosis. Canad. med. $\vec{C}$ Ass. J., 63, 138-143.

Smith, E. B., and Custer, R. P. (1946). Rupture of the spleen $\bigcirc$ in infectious mononucleosis. A clinicopathologic report of seven cases. Blood, 1, 317-333.

Spink, M. S. (1954). Spontaneous rupture of spleen in infectious mononucleosis. Lancet, 2, 144.

Springate, C. S. II, and Adelson, L. (1966). Sudden and unexpected death due to splenic rupture in infectious mononucleosis. Med. Sci. Law, 6, 215-217.

Stobbe, H. (1952). Milzruptur bei Mononucleosis infectiosa. Z. ges. inn. Med., 7, 1026-1035.

Ström, J. (1960) Infectious mononucleosis-is the incidence increasing? Acta med. scand., 168, 35-39.

Swedberg, B. (1959). Mononucleosis infectiosa-några reflexioner $i$ anslutning till tre fall med två dödsfall. Svenska Läk.-Tidn., 56, 2409-2415.

Thomsen, S. (1942). Studier over Mononucleosis infectiosa paa Basis af 549 Tilfalde. Munksgaard, Copenhagen.

Thomsen, S., and Vimtrup, B. (1939). 6 lethale tilfaelde af $\delta$ mononucleosis infectiosa. Nord. Med., 4, 3295-3299.

Trémolières, F., Lereboullet, J., and Duret, M. (1939). Mononucléose infectieuse à forme hépato-splénique sans $O$ adénopathies. Bull. Soc. méd. Hôp. Paris, 55, 690-698.

Verliac, F., Lamelin, J.-P., and Magloire, C. (1963). Deux complications inhabituelles de la mononucléose infectieuse. $\frac{9}{9}$ Encéphalite mortelle et méningomyélite. Bull. Soc. méd. Hôp. Paris, 114, 179-184.

Werner, W. (1954). Zur Pathologie der Mononucleosis infectiosa. Virchows Arch. path. Anat., 326, 155-171.

West, J. P. (1896). An epidemic of glandular fever. Arch. Pediat., $\widetilde{\Omega}$ $13,889-900$.

Worlledge, S. M., and Dacie, J. V. (1969). Haemolytic and other $N$ anaemias in infectious mononucleosis. In Infectious Mononucleosis, edited by R. L. Carter and H. G. Penman, p. 94. Blackwell, Oxford.

Wunderlich, P., Rupprecht, E., and Irmscher, J. (1967). Uber 0 eine tödliche Lungenkomplikation der infektiösen Mononucleose. $Z$. Kinderheilk., 98, 95-106.

Ziegler, E. E. (1944). Infectious mononucleosis: report of a fatal case with autopsy. Arch. Path., 37, 196-201.

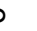

